\title{
Injury mechanisms of ankle fractures with dislocation and analysis of differences on functional outcome
}

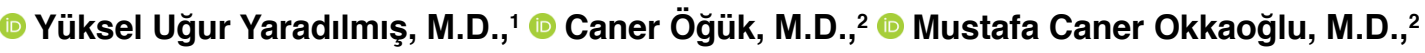

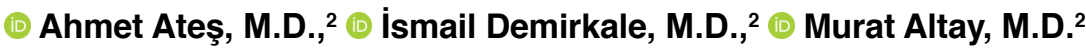 \\ ${ }^{1}$ Department of Orthopaedics and Traumatology, Çankırı State Hospital, Çankırı-Turkey \\ ${ }^{2}$ Department of Orthopaedics and Traumatology, University of Health Sciences, Keçiören Training and Research Hospital, Ankara-Turkey
}

\begin{abstract}
BACKGROUND: In the existing classifications, no importance is given to dislocations accompanying ankle fractures. The present study aims to investigate differences in injury mechanisms of ankle fractures with concomitant dislocation injury in respect of functional outcomes and complications.

METHODS: A retrospective evaluation was carried out of 285 patients who underwent surgery in our clinic for an ankle fracture between January 2012 and December 2018. A comparison was made of functional scores and complications between the patients with ankle fracture with dislocation (AF-D group) and patients with ankle fracture without dislocation (AF-WD). The correlation of dislocation with current classifications (Lauge-Hansen and Danis-Weber) and the effects on functional outcomes were also evaluated. In addition to functional scores, a record was also made for each patient of infection during follow-up, soft-tissue defect, malalignment, non-union, arthrosis and Reflex Sympathetic Dystrophy Syndrome (RSD).

RESULTS: The mean age of the patients was $44.7 \pm 12.04$ years (range, 18-72 years) and the mean follow-up period was 3.2 years. Ankle fracture with dislocation was observed in 88 (30.8\%). Similar functional results were determined in the AF-WD and AF-D groups with mean AOFAS $84.05 \pm 10.5$, and $80.33 \pm 9.47$, respectively $(p=0.379)$, and mean VAS scores of $I \pm 0.5$ and $1.23 \pm 0.48$, respectively $(p=0.117)$. When the AOFAS values of the dislocation function results were evaluated according to the Lauge-Hansen and Danis-Weber subgroups, no significant difference was observed $(p=0.562,0.723)$. Arthrosis was seen in two of the AF-WD group and seven of the AF-D group ( $p=0.004$ ). RSD was determined in two of the AF-WD group and in 10 of the AF-D group ( $p=0.000$ ). From a medico-legal perspective, patients should be informed about arthrosis, and RSD is another significant problem encountered in this patient group.
\end{abstract}

CONCLUSION: Although dislocation accompanying ankle fracture was not seen to worsen functional results, arthrosis and RSD were determined more often in these patients.

Keywords: Ankle fracture; AOFAS; arthrosis; complications; dislocation; functional results; unstable fracture.

\section{INTRODUCTION}

Ankle fractures (AF) constitute approximately $10 \%$ of all fractures. ${ }^{[l]}$ The most common mechanism of injury is rotational forces or falls at the same level. ${ }^{[2]}$ While stable fractures can be treated conservatively, unstable fractures require surgical treatment. ${ }^{[3]}$ Unstable ankle fractures include lateral malleolar fractures with talar displacement, $>3 \mathrm{~mm}$ displacement in the lateral malleolus, bimalleolar fractures and trimalleolar fractures. Although good functional results are obtained after surgical treatment, comorbidities (diabetes mellitus) and age (osteoporosis) are at the forefront of risk factors for poor functional results. ${ }^{[4-6]}$

In patients with ankle fracture with dislocation, bigger soft-tissue damage, cartilage damage or talus lesions are an-

Cite this article as: Yaradılmış YU, Öğ̈̈k C, Okkaoğlu MC, Ateş A, Demirkale İ, Altay M. Injury mechanisms of ankle fractures with dislocation and analysis of differences on functional outcome. Ulus Travma Acil Cerrahi Derg 2020;26:818-825.

Address for correspondence: Yüksel Uğur Yaradılmış, M.D.

Çankırı Devlet Hastanesi, Ortopedi ve Travmatoloji Kliniği, Çankırı, Turkey

Tel: +90 376 - 2132727 E-mail: ugur_yaradilmis@outlook.com

Ulus Travma Acil Cerrahi Derg 2020;26(5):818-825 DOI: 10.14744/tjtes.2020.57034 Submitted: 20.06.2019 Accepted: 19.01.2020 Online: 09.09.2020

Copyright 2020 Turkish Association of Trauma and Emergency Surgery 
ticipated and poorer functional results can be expected associated with these lesions. Just as soft-tissue trauma may cause infection or wound site problems, cartilage and talus lesions can be a reason for early post-traumatic arthrosis in the long-term. Cartilage tissues, soft-tissue and a robust ligament structure, which is important in ankle stability, can be best evaluated with magnetic resonance imaging (MRI), but the direct effects on functional results are not known. While some studies have reported that ankle fracture with dislocation in SER4 (supination-external rotation) and PER4 (pronation-external rotation) injuries could be a factor for poor functional results, there has been no evaluation of arthrosis. ${ }^{[7-9]}$

The Lauge-Hansen and Danis-Weber classifications are often used in ankle fractures. In the Lauge-Hansen classification, fractures are classified according to the injury mechanism and the position of the foot at the time of the injury (supination-pronation) and the forces affecting the foot at that time (abduction, adduction, eversion). ${ }^{[10]}$ In the Danis-Weber classification, fractures are classified according to the level of the fracture in the fibula. ${ }^{[1]}$ Dislocations accompanying the fractures are not mentioned in either classification. To our knowledge, there is no information in the literature about the orientation of the dislocation deformity, frequency, relationship with fractures or correlations with existing classifications.

The present study aims to investigate differences in injury mechanisms of ankle fractures with concomitant dislocation injury in respect of functional outcomes and complications. This study also aimed to investigate differences in respect to the correlation of functional outcomes of ankle fractures with dislocations with current classifications.

\section{MATERIALS AND METHODS}

A retrospective evaluation was made of 322 patients who underwent surgery in our clinic for an ankle fracture between January 2012 and December 2018. A total of 37 patients were excluded from this study because of multi-trauma $(n=2)$, open fracture $(n=3)$, exitus $(n=2)$, the anatomic reduction could not be achieved $(n=10)$ and data could not be obtained $(n=20)$. Thus, the evaluation was carried out on a total of 285 patients who were aged 18-72 years, did not have a pilon fracture and had at least a I-year follow-up period. Age, gender, affected side and accompanying dislocations were recorded. Surgery performed according to the following indications: Any talar displacement, displaced isolated medial or lateral fracture, displaced bimalleolar fracture posterior malleolus fracture higher than $>\% 25$ or $>2 \mathrm{~mm}$ step-off. A fracture-dislocation was diagnosed when radiographs demonstrated no apposition of the tibia and talus on either the anteroposterior or lateral view. In patients with ankle fractures with dislocation, the relationship of the orientation of the dislocation with the fracture was noted. The Lauge-Hansen and Danis-Weber classifications were applied and the relationships with the dislocations were determined. The patients were grouped as ankle fracture with dislocation (AF-D) and ankle fracture without dislocation (AF-WD), and the functional scores and complications were compared between these groups.

The correlation between the classification systems (Lauge-Hansen and Danis-Weber) and the functional results was evaluated. In addition to the functional results, a record was made for all patients in both the AF-D and AFWD groups of infection during follow-up, soft-tissue defect, malalignment, non-union, arthrosis and Reflex Sympathetic Dystrophy Syndrome (RSD).

\section{Preoperative Evaluation}

AF-D patients were applied with a reduction in the Emergency Department and were immobilised with a short-leg splint. Daily soft-tissue evaluation for surgery was carried out with the wrinkle test. In the wound site evaluation, the reduction was carefully checked and the short-leg splint application was continued under the supervision of an orthopaedic and traumatology doctor. Surgical planning was done by evaluating ligament injuries on $x$-ray of the tibiofibular clear space, syndesmosis with tibiofibular coverage, medial gap (>6 mm) and deltoid injury.

\section{Surgical Technique}

The patient was positioned supine on a radiolucent operating table. Lateral and medial malleolar fractures were determined. First, osteosynthesis was applied with lateral malleolar plate screw (tubular 1/3 or anatomic plate), followed by fixation with medial malleolar cannulated screw (3.5 or 4.5 screw). For patients with a positive modified cotton test in the syndesmosis examination, syndesmosis fixation was applied with a 3.5 screw and plate using three or four cortexes according to the surgeon's preference. Fractures bigger than $25 \%$ of the joint or with posterior malleolar fracture displacement were fixated. The deltoid injury was evaluated with the stress graph after syndesmosis fixation. During the operation, the reduction was evaluated as fibula length and intra-articular step-off $<2 \mathrm{~mm}$.

\section{Follow-up}

For soft-tissue healing, s short-leg splint was applied to patients for two weeks, after which it was removed and joint movements were started. In patients with deltoid ligament injury, the splint was continued for four weeks. Weight-bearing was permitted after six weeks for patients applied with syndesmosis fixation and after four weeks for those where it was not applied. Partial weight-bearing was achieved in all patients at a maximum of six weeks postoperatively and full weight-bearing at eight weeks. Non-union was evaluated as pain in the fracture line at six months postoperatively and non-visualisation of the union in three cortices. Arthrosis was diagnosed with the visualisation of sclerosis and loss of joint 
space on the direct radiograph and was classified according to the Takakura Classification system. ${ }^{[12]}$ RDS was diagnosed according to the Vieldman diagnostic criteria. ${ }^{[13]}$

\section{Ethical Approval}

Informed consents were taken routinely before surgery in our clinic. All of the study procedures met the ethical standards of the institutional and national research committees and all of the tenets of the 1964 Helsinki declaration. Written informed consent was obtained from all the participants. Approval for this study was granted by the Ethics Committee of Keçiören SUAM Hospital.

\section{Statistical Analysis}

Data obtained in the study were analyzed statistically using SPSS vn 22 software. Qualitative variables were stated as number $(\mathrm{n})$ and percentage (\%) and quantitative variables as mean, minimum and maximum values. The conformity of the data to normal distribution was assessed using the Kolmogorov-Smirnov test, and normal distribution was not observed. The AF-D and AF-WD groups were compared statistically using the Mann-Whitney $U$ test. Complications in the groups were compared using the Chi-square test. The Kruskal Wallis test was applied to evaluations of more than one group according to the Lauge-Hansen and Danis-Weber classifications. For subgroups of SER, PER, Weber B and C, evaluations were made again with paired ANOVA. A value of $\mathrm{p}<0.05$ was accepted as statistically significant.

\section{RESULTS}

The total of 285 patients comprised 155 males and 130 females (M/F: I.2/I) with a mean age of $44.7 \pm 12.04$ years were included in this study. The mean follow-up period was 3.2 years (range, $\mathrm{I}-7$ years). The patient data are shown in Table I.

Table I. Demographic data of the patients

\begin{tabular}{|c|c|c|c|}
\hline & $\begin{array}{l}\text { Ankle fracture without } \\
\text { dislocation (AF-WD) }\end{array}$ & $\begin{array}{l}\text { Ankle fracture with } \\
\text { dislocation (AF-D) }\end{array}$ & $\begin{array}{l}\text { Total } \\
\text { n (\%) }\end{array}$ \\
\hline Patients, n (\%) & $197(69.2)$ & $88(30.8)$ & \\
\hline Age & $40.1(20-68)$ & $54.7(21-72)$ & $44.7 \pm 12.04$ \\
\hline \multicolumn{4}{|l|}{ Gender } \\
\hline Male & 107 & 48 & $155(45.6)$ \\
\hline Female & 90 & 40 & $130(54.4)$ \\
\hline \multicolumn{4}{|l|}{ Side } \\
\hline Right & 97 & 46 & $143(50.1)$ \\
\hline Left & 100 & 42 & 142 (49.9) \\
\hline Body mass index & $27.6(24-38)$ & $28.4(23-37)$ & $27.8 \pm 4.54$ \\
\hline \multicolumn{4}{|l|}{ Lauge-Hansen, n (\%) } \\
\hline Supination-external rotation & 155 & $52(25.1)$ & \\
\hline Pronation-external rotation & 21 & $22(4 I)$ & \\
\hline Pronation-adduction & 4 & $13(76)$ & 0.010 \\
\hline Supination-adduction & 18 & I (5) & \\
\hline \multicolumn{4}{|l|}{ Danis-Weber, n (\%) } \\
\hline A & 18 & I (5) & \\
\hline B & 155 & $52(25.1)$ & 0.090 \\
\hline C & 25 & $35(58.3)$ & \\
\hline AOFAS (final score) & $84.05 \pm 10.5$ & $80.33 \pm 9.47$ & 0.379 \\
\hline Visual Analog Score & $\mathrm{I} \pm 0.5$ & $1.23 \pm 0.48$ & 0.117 \\
\hline Sudeckatrofi, n (\%) & $2(1)$ & $10(11)$ & 0.000 \\
\hline Artrosis, n (\%) & $2(1)$ & $7(8)$ & 0.004 \\
\hline Infection, n (\%) & $2(1)$ & I (I) & 0.680 \\
\hline Soft tissue, n (\%) & I (0.5) & I (I) & 0.580 \\
\hline Nonunion, n (\%) & $\mathrm{I}(0.5)$ & $2(2)$ & 0.112 \\
\hline Surgery time (minute/patients) & $64.1(30-70)$ & $72.1(40-96)$ & 0.260 \\
\hline
\end{tabular}

AOFAS: American Orthopaedic Foot\&Ankle Society. 
The fractures were isolated malleolar in 115 patients (II3 lateral, 8 medial), bimalleolar in 98, and trimalleolar in 72. According to the Lauge-Hansen classification, the injuries were observed to be 207 SER, 43 PER, I7 PAD and I8 SAD. According to the Danis-Weber classification, the injuries were 60 type $C, 207$ type $B$ and 18 type $A$.

Of the 285 patients with an ankle fracture, ankle fracture with dislocation was observed in 88 (30.8\%). In all the patients with dislocation, the dislocation was observed in the coronal plane. The lateral dislocation was observed in SAD injury in one patient, and medial dislocation in 87. No isolated sagittal dislocation was observed. Of the patients with dislocation in the coronal plane, dislocation was observed in the sagittal plane in 37 . The dislocations in the sagittal plane were observed in the anterior. All of the anterior dislocations were posterior malleolar fractures. Dislocations were observed in 22 PER, I 3 PAD, 52 SER and one SAD injuries. Examples of ankle fractures with dislocation with the classification subtypes are shown in Figures I, 2, 3 and 4.
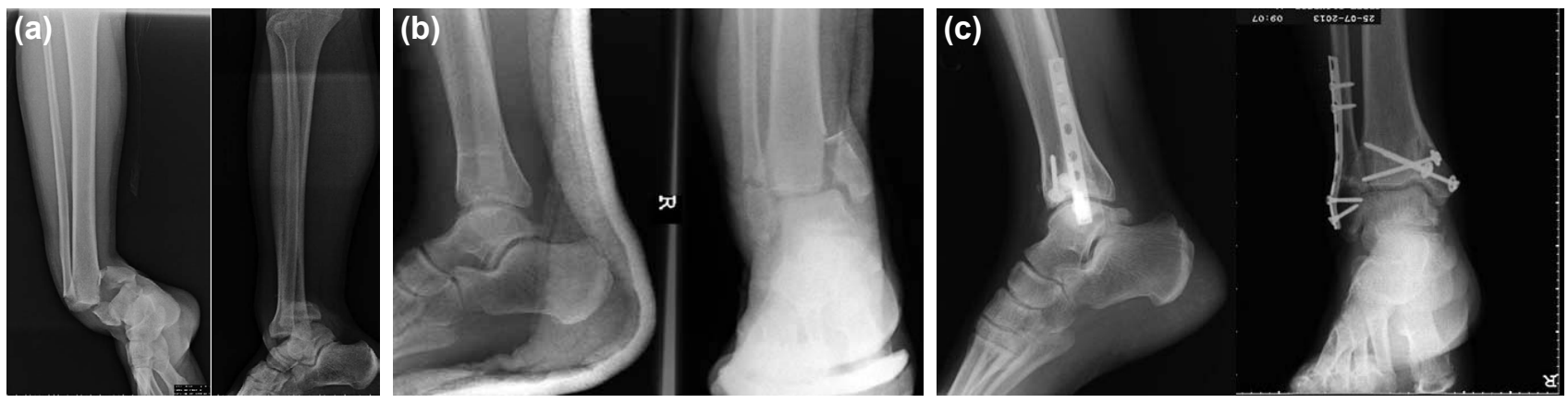

Figure 1. Ankle fracture with dislocation for Weber A or SAD: (a) preoperative grafy, (b) preoperative graphy after reduction, (c) postoperative grafy on the $6^{\text {th }}$ month.
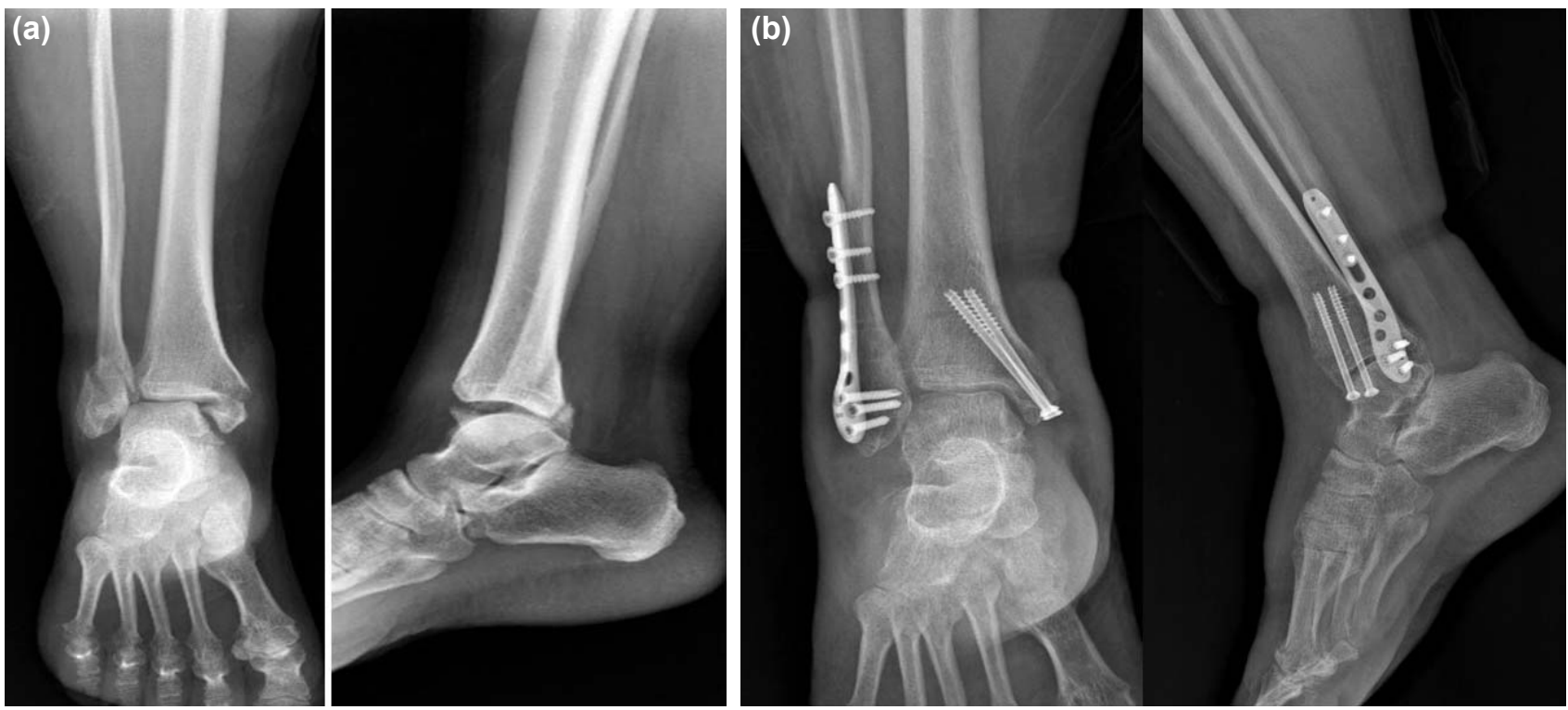

Figure 2. Ankle fracture with dislocation for Weber B or SER: (a) preoperative grafy, (b) postoperative grafy on the $6^{\text {th }}$ month.
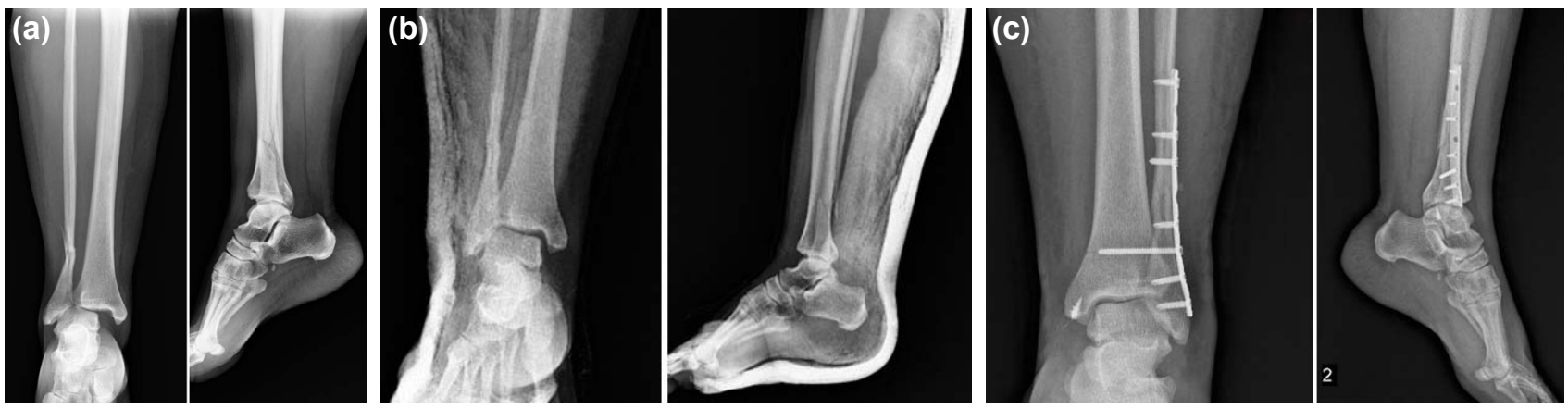

Figure 3. Ankle fracture with dislocation for Weber C or PER: (a) preoperative grafy, (b) preoperative grafy after reduction, (c) postoperative grafy on the $6^{\text {th }}$ month. 

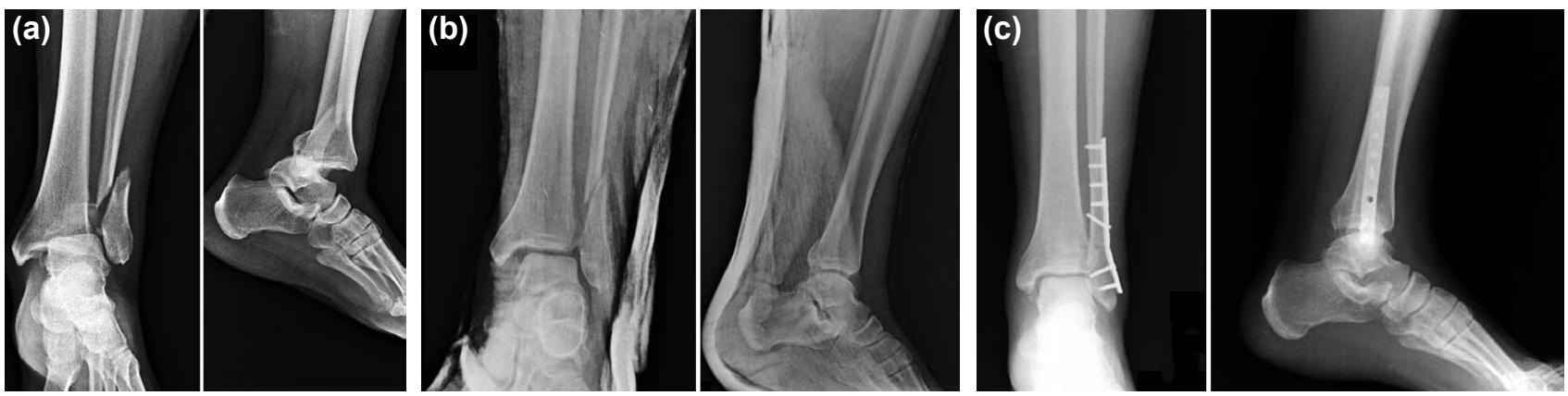

Figure 4. Ankle fracture with dislocation for Weber C or PAD: (a) preoperative grafy, (b) preoperative grafy after reduction, (c) postoperative grafy on the $6^{\text {th }}$ month.

The American Orthopedic Foot Ankle Society (AOFAS) values of the AF-WD and AF-D groups were determined as mean $84.05 \pm 10.5$, and $80.33 \pm 9.47$, respectively $(p=0.379)$, and the mean Visual Analog Scale (VAS) scores were $I \pm 0.5$ and $1.23 \pm 0.48$, respectively $(p=0.117)$. No difference was determined between the dislocation functional results in the AOFAS values and the Lauge-Hansen and Danis-Weber subgroups $(p=0.562, p=0.723)$. The effects on the results of the frequently seen subgroups of dislocation (SER, PER, Weber, $B$ and $C$ ) were evaluated separately and similar results were observed (Table 2).

When the 28 patients with AOFAS $<70$ were examined, 10 patients were in the AF-D group and 18 in the AF-WD group, and no correlation was determined between dislocation and low AOFAS $(p=0.728)$. A significant correlation was determined between AOFAS <70 and age $(56.7 \pm 10.14$ years) and diabetes $(n=10,35 \%)$.

Complications were examined of soft-tissue defect, infection, non-union, arthrosis and RSD. Arthrosis was determined in two (I\%) of the AF-WD group and seven ( $8 \%$ ) of the AF-D group $(p=0.004)$. The patients with arthrosis were classified as Stage I and Stage 2 according to the Takakura classification system. RSD was determined in two (I\%) of the AF-WD group and in $10(11 \%)$ of the AF-D group $(p=0.000)$. Superficial infection developed in two (I\%) patients with AF-WD and one $(I \%)$ AF-D $(p=0.680)$. All these infections recovered with oral antibiotics with no requirement for debridement and implant removal. The soft-tissue defect was seen in one $(0.5 \%)$ patient in the AF-WD group and one (I\%) patient in the AFWD group $(p=0.580)$, which were treated with debridement and dressing with no requirement for graft or flap (Table I).

\section{DISCUSSION}

Although successful results are obtained at a high rate in the surgical treatment of unstable ankle fractures, there is still a patient group with low functional results. In a prospective follow-up study of 230 ankle fractures, Egol et al. ${ }^{[14]}$ reported high AOFAS values in $90 \%$ of the patients, and that in the $10 \%$ with low AOFAS values, factors of age $>40$ years, female gender, ASA score $\geq 2$ and diabetes were found to affect poor

Table 2. Comparison of the final AOFAS

\begin{tabular}{lccc}
\hline & $\begin{array}{c}\text { Ankle fracture without } \\
\text { dislocation (AF-WD) }\end{array}$ & $\begin{array}{c}\text { Ankle fracture with } \\
\text { dislocation (AF-D) }\end{array}$ & $\begin{array}{c}\text { Total } \\
\text { n (\%) }\end{array}$ \\
\hline Lauge-Hansen & & & 0.562 \\
Supination-external rotation & $83.61 \pm 11.2$ & $80.12 \pm 10.2$ & 0.881 \\
Pronation-external rotation & $85.25 \pm 6.92$ & $80.8 \pm 8.45$ & 0.829 \\
Pronation-adduction & $84 \pm 6.92$ & $84 \pm 3.46$ & 1.00 \\
Supination-adduction & $84.72 \pm 9.82$ & 64 & 0.000 \\
Danis-Weber & & 64 & 0.723 \\
A & $84.72 \pm 9.82$ & $80.72 \pm 10.2$ & 0.000 \\
B & $83.61 \pm 11.2$ & $80.84 \pm 7.82$ & 0.789 \\
C & $84.22 \pm 7.17$ & & 0.948 \\
AOFAS & & $10(11 \%)$ & 0.723 \\
$<70$ & $18(9 \%)$ & 78 & \\
\hline 70 & 181 & & \\
\hline
\end{tabular}

AOFAS: American Orthopaedic Foot\&Ankle Society. 
functional results. Özkan et al. ${ }^{[15]}$ stated that good results in ankle fractures were obtained with anatomic restoration, provision of fibula length and functional syndesmosis. In another study that examined poor results in trimalleolar fractures, advanced age, high ASA score, high BMI, and fractures with dislocation were observed to be factors for poor functional results. ${ }^{[16]}$ Dislocation formed in ankle fractures suggests that the severity of the trauma continued and together with the dislocation, soft tissues are damaged more and there is an increased risk of cartilage injury. There are very few studies in the literature that have examined concomitant injuries in ankle fracture with dislocation.

In the current study of patients with an ankle fracture, the injuries, functional results and complications were examined in patients with ankle fractures with dislocation. The most significant finding of the study was that dislocation accompanying ankle fracture did not affect the functional results. However, arthrosis and RSD were observed more in patients with ankle fractures with dislocation.

In this study, first, an examination was conducted on the relationship between the orientation of AFD injuries and the current classifications. The dislocation was determined in $30.8 \%$ of the ankle fractures in this study. In all the AFD patients, the dislocation was observed in the coronal plane $(98 \%$ medial plane) and dislocation was observed in the sagittal plane $(97 \%$ anterior) in 37 (42\%) patients. While no isolated sagittal dislocation was observed, 34 (93\%) of the sagittal dislocations were posterior malleolar fracture. Although this subject has not been discussed in the literature, dislocations were usually observed to be medial, except in one SAD injury with lateral dislocation in the coronal plane. With the exception of this one patient, sagittal dislocations were observed to be anterior and $93 \%$ of the anterior dislocations were posterior malleolar fractures.

Ankle fractures are known to be most often SER injuries (55-60\%), followed by PER (20\%), and then, PAD and SAD injuries at lower rates. ${ }^{[17]}$ The relationship of the dislocation with which injuries is not known. Tantigate et al. ${ }^{[8]}$ examined the data of 118 patients and accompanying dislocation was observed in $28 \%$. The correlation between dislocation and Lauge-Hansen and Danis-Weber types has not been investigated in the literature. In the present study, according to the Lauge-Hansen (dislocations determined in SER 25\%, PER $41 \%$, PAD 76\%, SAD 5\%) and the Danis-Weber (C 58\%, B $25 \%$, A $5 \%$ ) classifications, dislocations were observed more in Weber $C$ and Lauge-Hansen PAD or PER subgroups $(p=0.90, p=0.010$, respectively). This statistical significance can be explained by a large number of patients, that dislocation was seen in SAD injury and there was a high number of cases with dislocation in PAD injury.

In the study by Tangigate et al. about I I 8 ankle fractures with dislocation, it was reported that dislocations were observed statistically more in elderly, female and diabetic patients. When the AOFAS scores were evaluated of 62 patients ( 18 with dislocation) with more than one year of follow-up, it was reported that with the exception of the pain score, no difference was observed in the functional scores. In the present study, similar functional results were obtained in the 197 AF-WD patients and the 88 AF-D patients with mean AOFAS scores of $84.05 \pm 10.5$ and $80.33 \pm 9.47$, respectively $(p=0.379)$. In the VAS evaluation, similar pain values were observed; AF-D group $I \pm 0.5$ and AF-WD group $1.23 \pm 0.48(p=0.117)$. When the $28(10 \%)$ patients with AOFAS $<70$ were examined, $9 \%$ of the AF-WD group had this value and II\% of the AF-D group $(p=0.723)$. While no relationship was determined between patients with dislocation and patients with low AOFAS score, a significant difference was determined in respect of age and diabetes in patients with low AOFAS score.

In the present study, patients with open fractures were not included, and there was no requirement for external fixator in any of the patients. Follow-up was applied with daily dressings and checking of the reduction, and when the wrinkle test was positive, open reduction and internal fixation were applied. In addition to arthrosis and RDS as frequent complications, non-union, malunion, soft-tissue problems and wound site infections may also be seen. Patients most at risk of complications are obese, osteoporotic and diabetic patients. ${ }^{[19]}$

Post-traumatic arthrosis can be observed in ankle fractures at not insubstantial rates, such as $14 \% .{ }^{[19]}$ When a good anatomic relationship cannot be established between the distal tibia and fibula, the tibiotalar joint biomechanics are impaired and post-traumatic arthrosis may develop. ${ }^{[20]}$ In a study of 57183 patients by SooHoo et al.," ${ }^{[1]}$ the poor union of fractures, talocrural instability and the severity of the fracture (trimalleolar fracture, open fracture) were observed as risk factors for post-traumatic arthrosis. However, in the same study, the need for fusion surgery because of arthrosis was seen to be $1 \%$. In the present study, while arthrosis was seen in $3.2 \%$ of patients, it was observed at $8 \%$ in the dislocation group. The patients observed with arthrosis did not wish to have fusion surgery, which was thought to be because the arthrosis was at an early stage (Takakura Stage I, 2).

There are high rates (23\%) of plate irritation findings in ankle fracture and implant removal may be required. ${ }^{[22]}$ Despite this high rate of plate irritation complaints, infection and wound site problems are seen at low rates. ${ }^{[2]}$ However, in the current AFD patients with high soft-tissue damage, no increase was observed in the rates of soft-tissue problems and infection. In literature, it has been reported that infection and soft-tissue problems can be observed at the rate of $1 \%$.

Non-union was observed in four patients (1.4\%). In two of them, PRP was applied in the 6th month and union was determined in the $9^{\text {th }}$ month. In I diabetic patient, revision surgery was applied in the second month because of implant failure, 
and the union was determined in the $7^{\text {th }}$ month. Revision surgery with autograft and plate osteosynthesis was applied to one patient in the $12^{\text {th }}$ month.

Reflex Sympathetic Dystrophy Syndrome (RSD) is often seen following an extremely painful injury. In the present study, RSD was determined in II\% of the patients with dislocation, which was a statistically significantly higher rate than in the patients without dislocation $(p=0.000)$. It should be kept in mind for AFD patients that in recent years there has been an increasing trend for the use of Vitamin $C$ to prevent RSD ${ }^{[23]}$ and this could perhaps be recommended routinely to these patients postoperatively.

In this study, evaluating the mechanism of injury of ankle fractures with dislocation and determining the relationships with current classifications, the results are strengthened by the number of patients included. A limitation of this study can be said to be the retrospective design. Evaluation of the bone injuries with CT could have provided a better evaluation of the bony structures. In addition, ligament injuries were not evaluated with MRI but with preoperative direct radiographs and physical examination findings. MRI evaluations of the dislocations, together with ligament injuries, could have increased the value of this study. However, the investigation of the relationship between dislocations and MRI findings has arisen as a subject for further studies.

\section{Conclusion}

Although dislocation accompanying ankle fracture was not seen to worsen functional results in the mid-term, arthrosis and RSD were determined more often in these patients. From a medico-legal perspective, patients should be informed about arthrosis and RSD, and the necessary precautions should be taken to prevent RSD in cases with ankle fractures with dislocation.

Ethics Committee Approval: Approved by the local ethics committee.

Peer-review: Internally peer-reviewed.

Authorship Contributions: Concept: Y.U.Y; Design: Y.U.Y., M.C.O.; Supervision: Y.U.Y., M.C.O.; Fundings: Y.U.Y., C.Ö.; Materials: Y.U.Y., C.Ö.; Data: Y.U.Y., C.Ö.; Analysis: Y.U.Y., I.D.; Literature search: Y.U.Y., A.A.; Writing: Y.U.Y., A.A.; Critical revision: Y.U.Y., M.A.

Conflict of Interest: None declared.

Financial Disclosure: The authors declared that this study has received no financial support.

\section{REFERENCES}

1. Schepers T, De Vries MR, Van Lieshout EM, Van der Elst M. The timing of ankle fracture surgery and the effect on infectious complications; a case series and systematic review of the literature. Int Orthop 2013;37:489-94. [CrossRef]
2. Thur CK, Edgren G, Jansson KÅ, Wretenberg P. Epidemiology of adult ankle fractures in Sweden between 1987 and 2004: a population-based study of 91,410 Swedish inpatients. Acta Orthop 2012;83:276-81.

3. Sanders D. Fractures of the ankle and tibial plafond. In: Lieberman JR, editor. AAOS comprehensive orthopaedic reviev 5th ed. New York: American Academy of Orthopaedic Surgeons; 2009.p.659-76.

4. Nilsson GM, Jonsson K, Ekdahl CS, Eneroth M. Unsatisfactory outcome following surgical intervention of ankle fractures. Foot Ankle Surg 2005;11:11-6. [CrossRef]

5. Ribeiro de Ávila V, Bento T, Gomes W, Leitão J, Fortuna de Sousa N. Functional Outcomes and Quality of Life After Ankle Fracture Surgically Treated: A Systematic Review. J Sport Rehabil 2018;27:274-83.

6. Dean DM, Ho BS, Lin A, Fuchs D, Ochenjele G, Merk B, et al. Predictors of Patient-Reported Function and Pain Outcomes in Operative Ankle Fractures. Foot Ankle Int 2017;38:496-501. [CrossRef]

7. Sculco PK, Lazaro LE, Little MM, Berkes MB, Warner SJ, Helfet $\mathrm{DL}$, et al. Dislocation is a risk factor for poor outcome after supination external rotation type ankle fractures. Arch Orthop Trauma Surg 2016;136:9-15. [CrossRef]

8. Warner SJ, Schottel PC, Hinds RM, Helfet DL, Lorich DG. FractureDislocations Demonstrate Poorer Postoperative Functional Outcomes Among Pronation External Rotation IV Ankle Fractures. Foot Ankle Int 2015;36:641-7. [CrossRef]

9. Hak DJ, Egol KA, Gardner MJ, Haskell A. The "not so simple" ankle fracture: avoiding problems and pitfalls to improve patient outcomes. Instr Course Lect 2011;60:73-88.

10. Lauge-Hansen N. Fractures of the ankle. II. Combined experimentalsurgical and experimental-roentgenologic investigations. Arch Surg 1950;60:957-85. [CrossRef]

11. Weber BG. Die Verletzungen des oberen Sprunggelenkes, 2nd edition. Berne, Switzerland: Verlag Hans Huber;1972.

12. Takakura Y, Tanaka Y, Kumai T, Tamai S. Low tibial osteotomy for osteoarthritis of the ankle. Results of a new operation in 18 patients. J Bone Joint Surg Br 1995;77:50-4. [CrossRef]

13. Veldman PHJM, Reynen JAM, Arnzt JE, Goris RJA. Sign and symptoms of reflex sympathetic dystrophy: prospective study of 829 patients. Lancet 1993;34:1012-6. [CrossRef]

14. Egol KA, Tejwani NC, Walsh MG, Capla EL, Koval KJ. Predictors of short-term functional outcome following ankle fracture surgery. J Bone Joint Surg Am 2006;88:974-9. [CrossRef]

15. Özkan Y, Öztürk A, Özdemir R, Atıcı T, Özbölük S. The results of surgical management of ankle fractures. Ulus Travma Acil Cerrahi Derg 2005;11:329-35.

16. Testa G, Ganci M, Amico M, Papotto G, Giardina SMC, Sessa G, et al. Negative prognostic factors in surgical treatment for trimalleolar fractures. Eur J Orthop Surg Traumatol 2019;29:1325-30. [CrossRef]

17. Jensen SL, Andresen BK, Mencke S, Nielsen PT. Epidemiology of ankle fractures. A prospective population-based study of 212 cases in Aalborg, Denmark. Acta Orthop Scand 1998;69:48-50. [CrossRef]

18. Tantigate D, Vosseller JT, Greisberg J, Ascherman B, Kirschenbaum J, Freibott C, et al. Functional outcomes after fracture-dislocation of the ankles. Foot \& Ankle Orthopaedics 2017;2:247. [CrossRef]

19. Irgıt K, Gökçen HB. Ayak bileği kırıkları sonrası görülen komplikasyonlar. TOTBİD Dergisi 2016;15:214-21. [CrossRef]

20. Ramsey PL, Hamilton W. Changes in tibiotalar area of contact caused by lateral talar shift. J Bone Joint Surg Am 1976;58:356-7. [CrossRef]

21. SooHoo NF, Krenek L, Eagan MJ, Gurbani B, Ko CY, Zingmond DS. Complication rates following open reduction and internal fixation of ankle fractures. J Bone Joint Surg Am 2009;91:1042-9. [CrossRef] 
22. Brown OL, Dirschl DR, Obremskey WT. Incidence of hardware-related pain and its effect on functional outcomes after open reduction and internal fixation of ankle fractures. J Orthop Trauma 2001;15:271-4. [CrossRef]
23. Zollinger PE, Tuinebreijer WE, Kreis RW, Breederveld RS. Effect of vitamin $\mathrm{C}$ on frequency of reflex sympathetic dystrophy in wrist fractures: a randomised trial. Lancet 1999;354:2025-8. [CrossRef]

\section{ORIJINAL ÇALIŞMA - ÖZET}

\section{Ayak bileği kırıklarına eşlik eden çıkıkların yaralanma mekanizmaları ve fonksiyonel sonuçlarındaki farklılıkların incelenmesi \\ Dr. Yüksel Uğur Yaradılmış, ${ }^{1}$ Dr. Caner Öğük, ${ }^{2}$ Dr. Mustafa Caner Okkaoğlu, ${ }^{2}$ Dr. Ahmet Ateş, ${ }^{2}$ Dr. İsmail Demirkale, ${ }^{2}$ Dr. Murat Altay ${ }^{2}$}

${ }^{1}$ Çankırı Devlet Hastanesi, Ortopedi ve Travmatoloji Kliniği, Çankırı

${ }^{2}$ Keçiören Eğitim ve Araştırma Hastanesi, Ortopedi ve Travmatoloji Kliniği, Ankara

AMAÇ: Mevcut sınıflandırmalarda ve literatürde çıkı̆ı̆n eşlik ettiği ayak bileği kırıklarına ayrıca önem verilmemiştir. Çalışmamızda, ayak bileği kırıklarına eşlik eden çıkıklardaki yaralanma mekanizması, fonksiyonel sonuçlar ve komplikasyonlar açısından farklılıkları belirlemeyi amaçladık.

GEREÇ VE YÖNTEM: Kliniğimizde Ocak 20।2-Aralık 2018 tarihleri arasında, ayak bileği kırı̆̆ı nedeniyle ameliyat edilen 285 hasta geriye dönük olarak incelendi. Kırıklara eşik eden çıkıklar kaydedildi. Çıkığın eşlik ettiği ayak bileği kırıkları (AF-D) ile çıkığın eşlik etmediği ayak bileği kırıkları (AFWD) arasında fonksiyonel skorlar ve komplikasyonlar karşılaştırıldı. Mevcut sınıflamalar (Lauge-Hansen ve Danis-Weber sınıflamaları) ile çıkığın birlikteliği ve fonksiyonel sonuçlara etkisi de değerlendirildi. Hastalar fonksiyonel değerler haricinde takiplerdeki enfeksiyon, yumuşak doku defekti, dizilim bozukluğu, kaynamama, artroz ve Refleks Sempatik Distrofi Sendromu (RSD) açısından da incelendi.

BULGULAR: Hastaların yaş ortalaması 44.7 12.04 (18-72), takip süresi 3.2 yıl idi. Hastaların 88'inde (\%30.8) ayak bileği kırıkları çıkıkla birlikte gözlendi. Çıkık hastalarının hepsinde koronal planda çıkık gözlenirken, 37 'sinde sagital planda da anteriora çıkı gözlendi. AF-WD ve AF-D gruplarında sırasıyla AOFAS 84.05 $\pm 10.5,80.33 \pm 9.47(p=0.379)$, VAS değerlendirmesi ise $I \pm 0.5,1.23 \pm 0.48(p=0.1$ I 7$)$ olmak üzere benzer fonksiyonel sonuçlar gözlendi. AOFAS değerleri Lauge-Hangene ve Danis-Webere göre değerlendirildiğinde altgruplar arası fark gözlenmedi $(p=0.562,0.723)$. AF-WD grubunda 2, AF-D grubunda 7 artroz gözlendi $(p=0.004)$. AF-WD grubunda 2, AF-D grubunda 10 hastada RSD gözlendi $(p=0.000)$.

TARTIŞMA: Ayak bileği kırığına eşlik eden çıkıkların, fonksiyonel skorlarda kötüleşmeye neden olmadığı gözlenmekle birlikte artroz ve RSD bu hastalarda daha sık bulundu. Mediko legal açıdan artroz hakkında hastaların bilgilendirilmesi gerekmekte ve RSD de bu hastalarda önemli bir sorun olarak karşımıza çıkmaktadır.

Anahtar sözcükler: AOFAS; artroz; ayak bileği kırıkları; çıkık; fonksiyonel sonuçlar; instabil kırık; komplikasyon.

Ulus Travma Acil Cerrahi Derg 2020;26(5):818-825 doi: 10.14744/tjtes.2020.57034 